\title{
Post-Militar Landscape Patrimony as a climate emergency escape to waterfront resilience.
}

\author{
Maria Rita PAIS, ULHT, Portugal \\ Katiuska HOFFMANN, ULHT, Portugal \\ Sandra CAMPOS, ULHT, Portugal
}

\begin{abstract}
Coastal Artillery Regiment (RAC) is a unit of the Portuguese Army with the mission of guaranteeing the coastal defense of the ports of Lisbon and Setúbal. The set consists of fixed, secret, camouflaged and fortified batteries, installed along the entrance to the Sado and Tejo rivers. The structures are equipped with heavy artillery pieces. RAC was deactivated in 1998 and its archive was recently declassified.

In times of technological advances, there is an inevitable change in the paradigm of military architecture. Technically obsolete structures have fallen into extinction. These territorial voids must be discussed in the inevitable territory reorganization. Should they display archeology or just be absorbed by surroundings? How to deal with post-military heritage? And lastly, how can we deal and operate in such a territorial resilience example, in a way to take profit from this particular long extension of waterfront regarding Climate Emergency.

Present paper is a result within two main research projects: "SOSClimateWaterfront" (Marie Skłodowska-Curie Research and Innovation Staff Exchange (RISE) program) and "Bunker architecture from mid 20th century and the post military Portuguese classified heritage" project. In this sense proposes a active research that means an accurate research about Portuguese bunkers and around military areas together with the discussion around the possible use of these areas as resilience areas to climate improvement within waterfronts around Lisbon.
\end{abstract}

\section{Keywords}

Bunker, Architecture, Patrimony, Resilience, Military 


\section{Introduction}

The Portuguese capital is located in front of the Atlantic Ocean, a plaza that joins 3 continents, as Europe's Atlantic gate. To travel along Lisbon coastline is to follow centuries of secret military knowledge developments for people and country survival.

This paper proposes a persual through the emergent research agendas in the critical analysis of postmilitary landscapes. The reading is based in a first-time research of Plan Barron of Defence of Lisbon and Setúbal Harbours, a 1938 project, design by General Barron, from United kingdom's War Office together with Portuguese Army. The plan presents a set of eight batteries along the Atlantic coast. We propose to present here a conceptual discussion about post-military patrimony in a territorial landscape scale, a preliminary essay to circumscribe and understand the object study as well as to understand what fields are we dealing with and what can we expect for these mega structures. Plan Barron is a witness to the resilience of a successful military plan, but it also bears witness to the resilience of twenty years of emptiness and ruin, since 1999, when it was officially deactivated. The eighty years of functional existence have created a landscape and a very particular territory, protected by national military legislation that during this time physically hides the military complex. The current result is a rich set of memories, history, architecture, museological heritage and an ecosystem still protected by isolation.

Considering ecological and waterfront contemporary problematics and the opportunity to inherit this new territorial set, we try to discuss here the possibility to profit from having a legal and conceptual possibility to intervene in this territory in a larger scale, this time to protect sea water-level rising and ecological improvements in the area.

This paper proceeds through five specific interpretative resilience concepts that are now being explored in our research:

- First, it provides a selective overview about the key characteristics of Plan Barron of Defence of Lisbon and Setúbal Harbours.

- Second, it introduces a resilient physical and material evidence of an anthropofossil of a territory scale.

- Third, it presents a military camouflaged territory, a resilient continuous landscape.

- Fourth, it presents a military inherence to a civil community.

- Fifth, it brings one of humanity's biggest problematics, climate change, particularly along the coast.

\section{Techno-estetic Resilience: Panoptic Territorial cluster}

The Plan Barron of Defence of Lisbon and Setúbal Harbours, which we present in this article, refers, according to the description taken from Raposa Battery dossier, affected to Direção da Arma de Engenharia archive, "to the set of Batteries and attached bodies that serve them, located in order to defend the ports"1.

The strategy used to establish the project started from the identification of vulnerable areas in the Lisbon region (the city, its anchorage, Banática, Alfeite, Barreiro, Barcarena, among others) and those of Setúbal, (the city and its anchorage), considering that these could be affected by cruisers cannons fires of the Washington Treaty, with a maximum range of thirty-two kilometres. From the midpoints of the vulnerable

1 Translation from the authors 
zones, arcs of circles were drawn, with the radius of this maximum range (thirty-two kilometres), fixing a dangerous line in the outline of the set of arcs that delimit the space from which enemy ships can reach the points vulnerable areas. This "line" is called the "bombing arch" on the map that accompanies the description and that we present below.

Based on the analysis of enemy attack danger zone, the plan outlines in detail a set of surveillance and defence structures, arranged at strategic points along the coast, so that attacking the enemy before it is able to reach the defended territory.

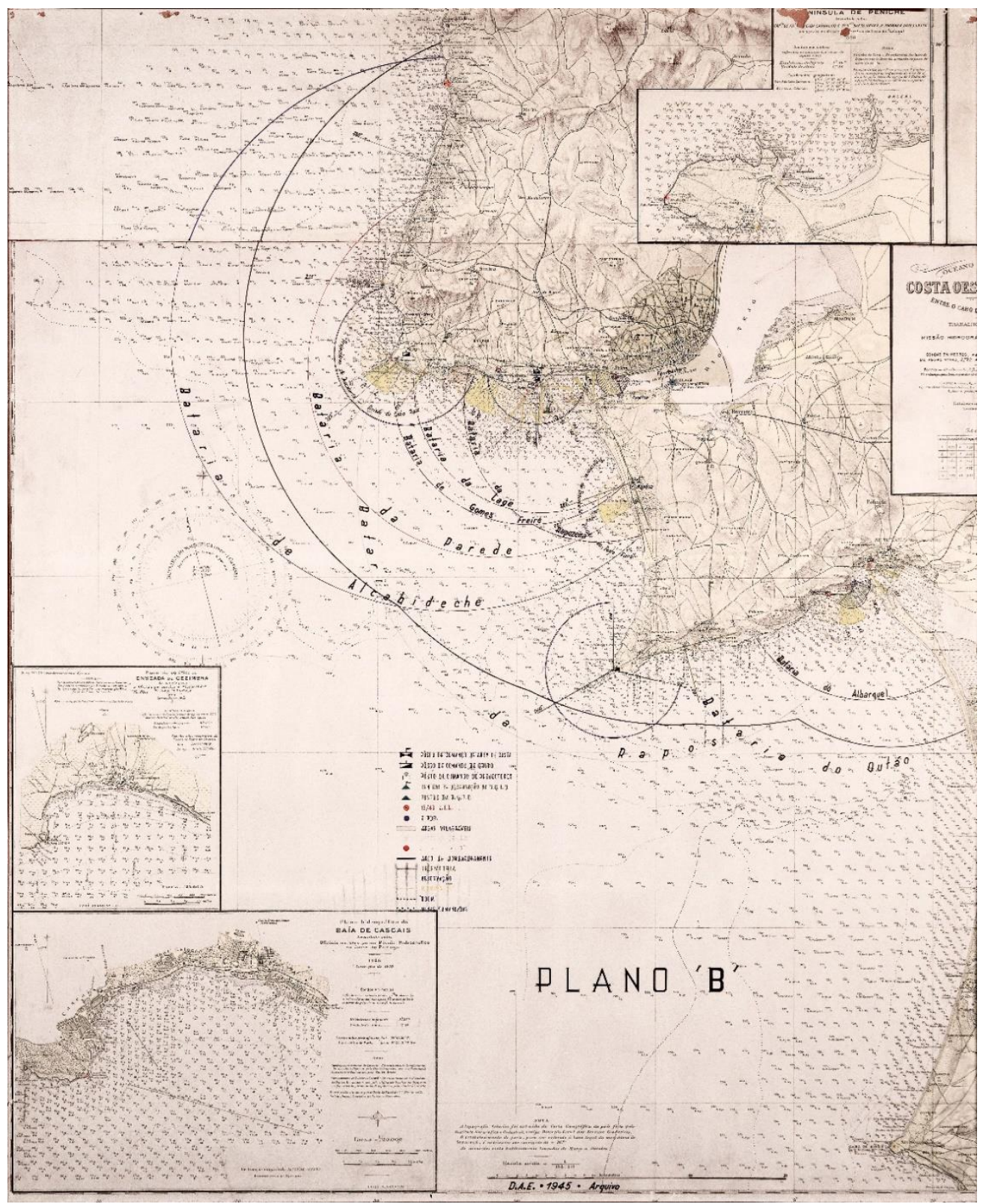

Figure 1. General Plan. Source: DAE

The plan proposes the construction of a set of new fortifications and other constructions (command posts, observation posts, shelters for projectors and other equipment, buried or submarine cables for data transmission, barracks, etc.) and works of adaptations in the existing fortifications that were included. From the original plan, some structures were removed at the time of their implementation, with the final set organised as follows:

-A Coast Defence Command, located in Puxa-freixe. 
-A counter bombardment zone, divided into two groups (North and South), formed by: Bataria de Alcabideche (North) and Bataria da Raposa (South), both artillery with three pieces of $23.4 \mathrm{~cm} / 47$, each and two general telemetry and observation networks (North and South).

-Two close-defence zones (Lisbon and Setúbal) consisting of two groups of close-defence coast artillery each: Bataria da Parede (Lisbon) and Bataria do Outão (Setúbal), both with three pieces of $15.2 \mathrm{~cm} / 47$ and two defence groups against small naval units (Bataria da Laje, artillery with three pieces of $15 \mathrm{~cm}$ CTR and Bataria do Bom Sucesso, artillery with two double pieces of $5.6 \mathrm{~cm} / 48$, in Lisbon, and Bataria de Albarquel (artillery with three pieces of $15 \mathrm{~cm} \mathrm{CTR)} \mathrm{in} \mathrm{Setúbal;} \mathrm{illuminated} \mathrm{areas,} \mathrm{areas} \mathrm{of} \mathrm{discovery} \mathrm{projectors,} \mathrm{a} \mathrm{strip}$ of commanded mines in the Tagus, two BOOMs (obstacle crossed in the river to control or block navigation giving protection to the interior of the port), anchorages and anchorages for inspection.

The system resulting from this project, connects and merges, forming a large optical territorial panopticon. As an individual structure, panopticon was idealised by Jeremy Bentham, makes use of architecture as a tool for organise and arrange space that leads to discipline through visual and physical contingencies. While old towers along the portuguese coast could work as a series of surveillance and attack posts along the maritime-coastal strip formalising the incarceration, not of the enemy, but of the territory to be defended, the Plan Barron follows Bentham's theory only in visual surveillance once spatial design is invisible in the form of a bunker. In this sense there is no auto-discipline, as Bentham conceived, the dissuasion starts when potencial enemies where contacted. At that very moment they couldn't attack, because they didn't know where to and also, because of Washington Treaty they couldn't use more than thirty-two kilometres range to reach Lisbon nor Setúbal. The system does not constitute a wall, since it is possible to cross the limits, but it is able, from a series of rules that regulate the entry of boats in the ports, forcing inspections in anchorages strategically positioned on the coast, to deter an invasion preventing access to ports and possible disembarkation of enemy troops.

In this sense, "Visibility is a trap" 2 and based on the concept of the panopticon as a machine with a deterrent effect on behavior, the Plan Barron designs a network of watch and attack posts, capable of disciplining and ensuring dominance over the behavior of individuals who enter the space delimited by the plan, integrated in a system, which Gilbert Simondon calls "technoestesthetics" 3 , since it performs an intercultural fusion between technique and aesthetics, in an intricate set of elements that allow an aesthetic enjoyment from the scale of the portholes to the scale of the territory. In this case, the importance of understanding the Plan Barron as an intricate set allows us to understand it, not only as a set of objects, but as a single, technical and beautiful machine.

\section{Material Resilience: Bunker Antropofossil in a territory scale}

From empirical science, the determination of the actual duration of the measured objects, like fossilised geodesic strata from witch fossils are excavated, like anthropocene ${ }^{4}$, measures the last human age, to the

${ }^{2}$ Michel Foucault. 1975. Surveiller et punir: Naissance de la prison. Paris.

${ }^{3}$ Gilbert Simondon. 1992. "Sur la techno-esthétique et Réflexions préalables à une refonte de l'enseignement". In Les Papiers du Collège International de Philosophie, 12. Paris: Collège international de philosophie.

4 Paul J.Crutzen and Eugene F.Stoermer. May 2000. "The "Anthropocene». The International GeosphereBiosphere Program (IGBP): A Study of Global Change of the International Council for Science (ICSU)". Global Change Newsletter 41 
present. The term anthropocene is a combination of the roots of the Greek words anthropo which means "human" and cene which means "new". All periods of the Cenozoic Era end in -cene and scientists are divided regarding its beginning, that can go back to Holocene Era. ${ }^{5}$

Anthropocene archeology on obsolete structures that can be read by its carbon negatives or fossils, reveals anthropofossil 6 , "the evidence of the anthropofossil" or the argument of human "ancestrality" which material is resilience.

Plan Barron of Defence of Lisbon and Setúbal Ports is considered here a post-military's "techno-esthetics" material resilience, a reference to Virilio's "Total War" ${ }^{7}$, resulting in a geodesic anthropocene strata. Also, because of its obsolence, this anthropocene territorial structure, as it was remembered by Virilio in he's Bunker Archeology can be seen as an "anthropofossil" that takes into account Meillassoux's "Speculative Realism" and "Speculative Materialism" categories in After The Finitude: chapter 1, "Primary Quality", property inseparable from the object, that don't depend on users, and in that sense, has an obsolete use Ancestrality; chapter 2, Metaphysics, Fideism, Speculation; chapter 3, The Principle of Factiality; chapter 4, witch reset us to Hume's problem, "Necessity of Laws of Nature", and Meillassoux proves that "Laws of Nature are Contingent", in contradiction of modalities, with no acceptable ground, and "Finitude" for contemporary thought.

In 1929, the line of investigation of the german archeologists Georg and Vera Leisner, bring them to Portugal with a dedicated mission to the revelation of 4000 monuments of megalithism, namely tapirs, where the skeletal structure of the bearing elements, probably to reproduce a mimicry of observing a natural skeleton, was camouflaged as topology simulacrum, on a privileged control view location. These anthropofossil structures are mostly concentrated in Reguengos de Monsaraz, Beiras and Cascais municipality. Leisner's reputation in the scientific community proves, as dating technics became accurate and reliable, that the anthropofossil of the Iberian Peninsula represent a civilization prior to Mesopotamia, in Iraq and Syria, considering even these days, the cradle of civilization, to the common global opinion.

The possibility of interest in studying megalithic anthropofossil, proved as camouflaged structures, in the 30's of the XX Century, (let's not forget the military intelligence advance in Ergonomy, Polymorphism, Genotype, and Bio-mimetics in the period between 1st and $2^{\text {nd }}$ World War), having inspired and contributed for the techno-aesthetics of both Plan Barron and Atlantic Wall, as builders of a reinforced concrete proto-brutalist defensive (military) architecture, with scars craved on the heritage of the delicacy of the material, in its natural and superficial appearance, precisely, and some few others natural inert, shaped aerodynamic exterior to resist extreme events, concrete reinforced structures instead of stone, both trying not to be revealed and camouflaging themselves in the landscape structures where they are embedded, to provide a panoramic, hidden and privileged visual horizon over the sea coast or reducing the surprise effect on the part of a predator or an enemy, will lead us to a comparative study.

Will the mid-20th century bunkers be anthropofossil of brutalism?

\footnotetext{
5 Paul J.Crutzen. December 2003. "How Long Have We Been in The Anthropocene Era?". In Dordrecht, vol.61, Issue 3, 251-257.

${ }^{6}$ Quentin Meillassoux. 2008. After Finitude - An Essay on the Necessity of Contingency. Translated by Ray Brassier. London: Continuum. The Philosophical Order series.

7 Paul Virilio. 1975. Bunker Archeology. Translated by George Collins. New York: Princeton Architectural Press.
} 
The anthropofossil concept corroborates the idea of Plan Barron post-military proto-brutalist resilience, built on a territorial scale, representing a cultural, social and historical human heritage with geophysical evidence.

\section{Militar Resilience: Military Camouflage as Resilience}

On February 10, 2010, after 24 months of construction, the new Cascais Hospital was inaugurated, a 45,863 $\mathrm{m} 2$ building inserted in a land at the time with military classification that passes into a Public State domain, in order to enable the construction on site of the new health unit. The change in ownership was the first obstacle to be circumvented, being followed by a complicated process of demolition of the bunker structures from the Battery of Alcabideche (1954), one of the eight Batteries part of the Plan Barron, from 1939. "They were all to be destroyed, but they spend in the first one, the explosives that were foreseen for the construction of the whole hospital" ${ }^{8}$, says Coronel Alpedrinha Pires ${ }^{9}$. The project was changed and the building was eventually erected over the underground of the remaining defensive structure, after the property was handed over by the Ministry of Defence to the Ministry of Health and then transferred to the company that has managed a public-private partnership for ten years. Naturally it would not hold out a traditional demolition, since it was calculated to withstand the explosion of war bombs.

Throughout the world and throughout the twentieth century, large sums were spent on war, on waging war, on preparing and avoiding it. In addition, the greatest material, technological and territorial advances come exactly from the needs of war. From an architectural point of view, perhaps the most interesting point of view of military architecture is that it is probably the most responsive and adaptable to events, probably much more than civil architecture. On the other hand, due to its secrecy, military architecture is probably the least known from a civil and academic point of view. The rules for the creation of military architecture are linked to technological events and respond to needs on a territorial scale.

Military architecture lives today from its camouflage, but it was not always like this, it evolves following the needs and military attack and above all defence techniques. We resume here three moments to better understand the role of camouflage today.

First period - From Roman wall to medieval fence

The Roman wall is used around cities or along strategic defence zones and consists in a linear wall in height and with great thickness, usually built in stone or brick. It has foundations, but its structure is in height, visually comprehensible for psychological deterrence and physically difficult to pass by people, animals and the few existing mechanical means.

During the first phase of the Middle Ages, the firing armament available was limited to devices that used as propelling elements the force resulting from flexion or torsion: the neurobalistic. Examples are the bow, the crossbow or the catapult.

Second Period - The bastion

\footnotetext{
8 Translation from the authors

${ }^{9}$ Coronel Alpedrinha Pires is the President of Associação de Amigos da Artilharia de Costa Portuguesa, Friends Association of Portugueses Coastal Artillery.
} 
The bastion results from the transition from neurobalistics to pyrobalistics ${ }^{10}$ and will determine innovations in the art of war and, by consequence, force changes in military architecture. The tower gradually gave way to the bastion and the buildings stopped developing in height to develop horizontally. The cannon, initially ineffective due to its weight and lack of firing precision, was improved throughout the 15th century. The modern stronghold first appeared in Italy at the end of the 15th century, having reached its maximum expression with Marechal Sébastien Le Prestre de Vauban, a French military engineer, who served under Louis XIV, in France, that has proposed rational and scientific methods merging engineering and social, common in the Age of Enlightenment. The main modifications were the curtain walls reduction of the height and base increase. The work was complete as an enormous topographic arrangement.

Third period - Circle of isolated forts

During the 19th century, military defence architecture changed dramatically. Between 1792 and 1852 there was an increase in the protection of mortars, which together with stronger casemates and weapons gave extra protection to the forts construction. In 1960, striated artillery appeared, a technology that greatly increased the power and precision of projectiles. Finally, the third technical novelty between 1885 and 1890 is the use of concrete to replace stone parliaments and the use of metal domes to protect artillery material. The fort starts to organize in isolation, forming circular sequences around the cities. These forts were isolated in a vast territory in strategic places in order to defend agglomerations and relevant places, such as bridges, railway lines or ports. As Major Morritz Ritter von Brunner, a Hungarian military officer says, the type and amount of hostile fire to be expected were the main criteria in fortress design ${ }^{11}$.

By this time, cities tear down their useless walls. Paris, Vienna, Brussels or Rome develop a new urbanism, opening to the surrounding countryside and dissolving the city with nature. Georges-Eugène Haussmann in Paris in the first half of the 19th century, Ildelfons Cerdà in Barcelona in the second half of the 19th century, Franz Joseph I in Vienna in the second half of the 19th century and Frederico Ressano Garcia in Lisbon in the last quarter of the century XIX, perform plans to update cities responding to this advent of the new military defence strategy.

The First World War started with the use of trenches dug in a direct war area, but a progressive hardening with reinforced concrete in small strategic points for the protection of communications, observation points and hospitals, authentic strong cities buried to give better conditions to soldiers. By 1916, German and Prussian high ranks militaries orders already suggested the use of more extensive concrete, starting in the first battle line.

The design of these structures aims camouflage: horizontality and low height of the interior space. The use of reinforced concrete by the Germans between 1914-18 is probably the first step in the use of reinforced concrete on a large scale internationally. Images of the battle fronts devastated after the war scenario often show pillow boxes as the only recognisable element, thus proving the importance of using concrete for its resilience on the ground. Here, the bunker represents resilience in a scenario of total destruction. Often, this resilience surpasses the natural order of the land, as it remains solid, but fallen by land movements on more vulnerable soils.

Plan Barron for the Defence of the Ports of Lisbon and Setúbal is based on the principles of territorial camouflage, as a form of defence and surprise attack on enemy approaches to the entry by sea in Lisbon or Setúbal. We have passed from stage one and two to three, following a decreasing visibility, although

${ }^{10}$ In the 14th century, the use of gunpowder as a driving force began, the pyrobalistic one, which allowed the development of new types of weapons such as the cannon and later the arcabuzes and pistol.

${ }^{11}$ Moriz Ritter von Brunner. Late 19th century. Der Festungskrieg. Wien 
maintaining great impact in urban and territorial structure. According to the classification of Neil Leach (2006), we consider that the architectural proposal of Plan Barron can be read as mimetry (mimicry), or a relationship between an organism and its surroundings. Quoting Rogers Caillois (1984), Leach develops this idea of mimetry in a similarity to Darwing's theory, as an imitation of the surroundings in the form of camouflage and more precisely a "morphological mimicry" or "three dimensional teleplasty". According to Caillois, it is like a dark space in which the object is stained by the darkness of the surroundings. In the case of the design of the bunkers of Plan Barron, mimesis enters a kind of crisis, because in many moments, the buried building is not distinguishable from the surroundings and enters a state of "psichasthenia", as Leach also refers. In Plan Barron the camouflage wanders between "psychasthenia" (from the outside) and the "Mask of Medusa" (from the inside), with the body covering by external objects, making a perfect imitation of the surroundings in terms of color and shape. Invisibility through camouflage is desired, "blending into the nature and becoming one with nature" (Leach, p77), enabling a strategic position in which defence is the best attack.

Soldiers play in these war-field supported by a strong expert knowledge. This relationship with surroundings gives them the necessary control. So, in this sense, the features of military control shape militarised landscapes and these militarised landscapes, as physical forms support control in space and political levels. Military landscapes are politics.

In the case of Plan Barron of Lisbon and Setubal Harbours Defence, a territorial panopticum as been drowned along almost $80 \mathrm{~km}$ of coast. Resilience here is shaped in this new landscape, not natural but built-in nature, camouflaged. The uniqueness of this shape should be studied and preserved to preserve the new cultural and natural heritage, as following generations should understand the courage of men regarding de defence of their territory.

\section{Civil resilience: inheritance as a future potential}

Civil life and architecture depend on the protection and peace feeling provided by militar structures. In this sense, civil resilience, has its foundations on the presumption of the active role that these structures have in protecting civilians. There is always a sense of separation, civilians and military have parallel existence and hardly meet. Furthermore, civilians and military live in secrecy regarding each other, military need secrecy to perform defence and civilians condone military secrecy for their own security. This status quo ensures a sense of mutual respect.

\section{Memory}

Since men's birth, civilians have filled public sphere with monuments, as souvenirs for virtues, failures, hopes or uncertains. These signs inherited from our past generations assure today's equilibrium. In the case of the Plan Barron of Defence for the Ports of Lisbon and Setúbal, civilian community is inheriting an extensive structure of enormous military and strategic relevance, currently abandoned. In itself, the inheritance of a territory so intricate and invisible may be unnoticed by community. How can these spaces be adopted by civil community if they are secret?

Future

These spaces often bring memories of nationalism and national identity, maybe though this can also unveil individual, community and public appeal.

Post-military landscapes are those with no military function, but where a former military function remains and remember its military origins. The study of military landscapes offers us the possibility to discuss the moral ideologies expressed in these places and how they might contribute to an ethics of peace and well 
being. We should also discuss about the tenacity of urban forms and lives of a military inheritance into a civilian present. First, because usually they where protected by legislation, and for that reason, they arrive many times untouched. In this sense they deserve to be studied to decide the best form to absorve it in existing funcional areas, as a memory testimony.

Going back to Vienna and its remarkable case study of heritage and transformation of military heritage that has strategically changed the city. "It is My will" was a decree by Franz Joseph I, in 1857, which began the construction work of the new democratic city, similar to the case of Paris. The architecture here draws the society of that moment with the destruction of the walls of a feudal society, the city could expand outwards, into the countryside and open the city to better housing quality. A new ring road, Ringstraße, took the place of the walls, and plans were made to fill the wide space left by the old 500m circular ring of protection. The emperor's architects also created large green and leisure spaces accompanied by cultural projects: a new City Hall building, university, opera and large museums in which the imperial collections of natural history and art were exposed to the public. This action transforms an enclosed city into a city open to the surrounding natural space and to culture and external dynamics, contributing to a substantial improvement of the inhabitants quality of life.

We found resilience in Vienna case, once, the existing void area that surrounded the walls was kept almost entirely, maintaining the memory of the past, but opening space to the new order of the times: political, social, cultural and individual.

\section{Climate resilience: post-militar comes to light}

Despite the immense discussion in the public sphere, climate change is already a scientific evidence, as are some of its consequences, such as rising temperatures and water levels. Despite the interest that these measurements have in the theme, in this paper we will not specifically discuss the various forecasts of climate change possible scenarios, they are referred to specialists and international authorities, as United Nations (UN), Laboratory for Satellite Altemetry (NOAA). UN estimates: (1) The concentration of Greenhouse gas (GHG) in the earth's atmosphere is directly linked to the average global temperature on Earth; (2) The concentration has been rising steadily, and mean global temperatures along with it, since the time of the Industrial Revolution; (3) The most abundant GHG, accounting for about two-thirds of GHGs, carbon dioxide (CO2), is largely the product of burning fossil fuels." ${ }^{12}$ And NOAA estimates sea level rise (not including glacial isostatic adjustment effects on the geoid) to be +0.2 to $+0.5 \mathrm{~mm} /$ year when globally averaged $^{13}$. It becomes difficult to calculate the actual values for the expected changes, given the large number of variables that are included in the calculations. However, we can say that "there is very high confidence that maximum global mean sea level during the last interglacial period ( 129 to $116 \mathrm{ka}$ ) was, for several thousand years, at least $5 \mathrm{~m}$ higher than present and high confidence that it did not exceed $10 \mathrm{~m}$ above present (...)"14. Between predictions and evidences, it seems obvious that sea level has been

12 In: https://www.un.org/en/sections/issues-depth/climate-change/

${ }^{13}$ In: https://www.star.nesdis.noaa.gov/socd/Isa/SeaLevelRise/LSA_SLR_timeseries.php

${ }^{14}$ J.A. Church, P.U. Clark, A. Cazenave, J.M. Gregory, S. Jevrejeva, A. Levermann, M.A. Merrifield, G.A. Milne, R.S. Nerem, P.D. Nunn, A.J. Payne, W.T. Pfeffer, D. Stammer and A.S. Unnikrishnan, 2013: "Sea Level Change". In: Climate Change 2013: The Physical Science Basis. Contribution of Working Group I to the Fifth Assessment Report of the Intergovernmental Panel on Climate Change [Stocker, T.F., D. Qin, G.-K. Plattner, M. Tignor, S.K. Allen, J. Boschung, A. Nauels, Y. Xia, V. Bex 
changing, so we may should take this into consideration when thinking about post-military related with waterfront. Architects, planners and specialists should predict scenarios discussing, its constrains but also predicting opportunities.

Climate Resilience actions generally propose to absorb stress, maintain a function in the face of external tensions that are imposed by climate changes and adapt, reorganise and evolve to more desirable configurations that improve the sustainability of the system, leaving it better prepared for the future impacts of climate issues.

Given the increasing awareness of climate change impacts, building climate resilience has become a major concern. The primary focus of climate resilience efforts is vulnerability to some of the environmental consequences of climate change. From this point of view, the set of eight bunker structures and the entire surrounding area distributed along the Atlantic coast are already points of climatic resilience, since they have been protected in a naturalised state by national law and kept in military secrecy, while Lisbon grew according to current urban laws. We found, therefore, eight relatively virgin cores aligned and strategically placed along the coast. This set already influenced the surrounding urban areas through the existing military areas protecting laws and interacted from a biological point of view with the natural surroundings. We believe this resilience should not be despise, by contrary, could be encouraged. The direct benefits of this solution stay in the reduction of vulnerability to climate change and improvement of water management (e.g. reduction in irrigation needs, improved water availability, better water quality and stabilisation of the groundwater table). There are also a large number of co-benefits such as increased carbon storage, increased productivity and diversification of agricultural products, recreational value of bunkers and sea, increased biodiversity, increased numbers of visitors due to new water-related events, and improvement in the quality of life of local inhabitants.

\section{Conclusion}

In Portugal, the impact of rising water levels across the coastal region is expected with the change of the coastline at numerous points and with greater severity in the areas of Viana do Castelo, Ria de Aveiro, Figueira da Foz, Tejo estuary, Sado estuary, and Faro estuary.

The present study allows to anticipate links of resilience for the eight structures belonging to Plan Barron of Defence of the ports of Lisbon and Setúbal. These links of resilience are based on the main characteristics of this structure from the point of view of possible asset classification, which together may define the main potentials of future existence. This paper exposes the issue and discusses it through the five points presented and goes on with three lines of reading as a way to start the problem.

- First, we present a potential for urban resilience, which adopts a greater dialogue between the urban fabrics in continuous growth and the stagnant military territories.

- Second, we launch a concept of ecological resilience, developed over decades of crystallisation that allowed the preservation and development of countless animal and plant species, which can now, through a controlled strategy, expand the existing ecosystems to the surrounding areas and even in a linear direction along the coast. This possibility is intended to prevent more spontaneous urban developments that put these ecosystems at risk.

and P.M. Midgley (eds.)]. Cambridge University Press, Cambridge, United Kingdom and New York, NY, USA. 
- Third, we propose to literally reveal the secret military heritage to the community. The recent declassification allows these areas to be re-allocated to the community, with its historical and possibly nationalist memories, transforming them into the idea of building a common good. This scenario, due to the secrecy of the architectural object, needs a vast educational work to raise awareness of this new cultural and architectural heritage, which can be realized through the safeguarding of physical and material heritage, allowing, through it, a concept of historical resilience, cultural and social. 


\section{References}

Bentham, J., 1791. Panopticon. Whithorn: Anodos Books.

Brunner, M. R. v., 1906. Der Festungskrieg. Wien: Seidel \& Sohn.

Caillois, R., 1984, vol.31. "Mimicry and Legendary Psychasthenia". Em: A. Michelson, ed. October. Cambridge: The MIT Press, pp. 16-32.

Crutzen, P. J., 2003. "How Long Have We Been in The Anthropocene Era?". Dordrecht, December, 61(3), pp. 251-257.

Crutzen, P. J. \& Stoermer, E. F., 2000. "The "Anthropocene"'. Global Change NewsLetter, May, Issue 41, pp. 17-18.

Foucault, M., 1975. Surveiller et punir: Naissance. Paris: Gallimard.

Hart, L., 1937. Europe in Arms. London: Faber.

Havlick, D., 2011. "Disarming nature: Converting military lands to wildfire refuges". Geographical Review, Volume 101, pp. 183-200.

Hourdequin, M. \& Havlick, D. G., 2011. "Ecological restoration in context: Ethics and naturalization of former military lands". Ethics Policy and Environment, Volume 14, pp. 69-89.

Kobayashi, U., 2012. Geographies of peace and armed conflict. London: Routledge.

Kulp, S. A. \& Strauss, B. H., 2019. "New elevation data triple estimates of global vulnerability to sea-level rise and coastal flooding". Nature, 10(4844).

Leach, N., 2006. Camouflage. Cambridge: MIT Press.

Majdalany, F., 1968. The Fall of Fortress Europe. London: Doubleday.

Meillassoux, Q., 2008. After Finitude - An Essay on the Necessity of Contingency. 1st ed. London: Continuum.

Morin, L., 1930. "The Utility of permanent Fortifications". Journal of the Royal Artillery, Volume LVII, pp. 491-505.

Prazeres, C. M., 1970. História Da Artilharia De Costa Em Portugal. Oeiras: Arquivo Histórico-Militar.

Simondon, G., 1992. "Sur la techno-esthétique et Réflexions préalables à une refonte de l'enseignement". Em: Les Papiers du Collège International de Philosophie. Paris: Collège international de philosophie.

Tello, A. J., 1991. Portugal na Segunda Guerra: 1941-1945. Lisboa: Vega.

Tello, A. J., 2005. O papel dos militares no processo de inovação e mudança no Portugal ContemporâneoUma Perspectiva de Conjunto. Nação e Defesa, Issue 112 - 3.a Série, pp. 103-136.

Vauban, S. L. P., 1700. Traité de l'attaque et de la deffence des places. Conservatoire numerique des Arts et Metiers ed. France: s.n.

Virilio, P., 1975. Bunker Archeology. Original ed. New York: Princeton Architectural Press.

Wilczkiewicz, M. Z., s.d. "Green space as a method of revitalization on post-industrial urban places following the New York's Parks (the High Line and Brooklyn Bridge Park).". Technical Transaction, Volume 109/19/6A, pp. 223-233.

Woodward, R., 2004. Military Geographies. Oxford: Blackwell Publishers. 
Sites with online open data source:

Climate Central: https://coastal.climatecentral.org/

United Nations Environment: https://www.unenvironment.org/unga/our-position/unep-and-climateemergency; and https://www.un.org/en/sections/issues-depth/climate-change/

Laboratory for Satellite Altimetry:

https://www.star.nesdis.noaa.gov/socd/Isa/SeaLevelRise/LSA SLR timeseries.php 